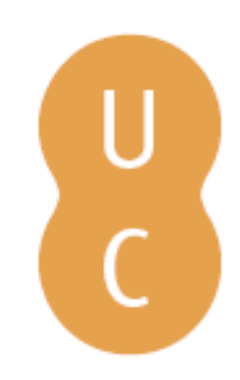

pnmbalina

Influence of fire frequency and epoch of prescribed burn on topkill rates in vegetation of Cerrado in Tocantins, Brazil

\begin{tabular}{|c|c|}
\hline Autor(es): & $\begin{array}{l}\text { Silva, Allan Deyvid Pereira da; Batista, Antonio Carlos; Giongo, Marcos; } \\
\text { Santos, Micael Moreia; Neto, Eduardo Ganassoli; Carvalho, Edmar } \\
\text { Vinícius de; Machado, Igor Eloi Silva; Cachoeira, Jader Nunes }\end{array}$ \\
\hline Publicado por: & Imprensa da Universidade de Coimbra \\
\hline $\begin{array}{l}\text { URL } \\
\text { persistente: }\end{array}$ & URI:http://hdl.handle.net/10316.2/44541 \\
\hline DOI: & DOI:https://doi.org/10.14195/978-989-26-16-506_24 \\
\hline Accessed: & 26-Apr-2023 10:32:47 \\
\hline
\end{tabular}

A navegação consulta e descarregamento dos títulos inseridos nas Bibliotecas Digitais UC Digitalis, UC Pombalina e UC Impactum, pressupõem a aceitação plena e sem reservas dos Termos e Condições de Uso destas Bibliotecas Digitais, disponíveis em https://digitalis.uc.pt/pt-pt/termos.

Conforme exposto nos referidos Termos e Condições de Uso, o descarregamento de títulos de acesso restrito requer uma licença válida de autorização devendo o utilizador aceder ao(s) documento(s) a partir de um endereço de IP da instituição detentora da supramencionada licença.

Ao utilizador é apenas permitido o descarregamento para uso pessoal, pelo que o emprego do(s) título(s) descarregado(s) para outro fim, designadamente comercial, carece de autorização do respetivo autor ou editor da obra.

Na medida em que todas as obras da UC Digitalis se encontram protegidas pelo Código do Direito de Autor e Direitos Conexos e demais legislação aplicável, toda a cópia, parcial ou total, deste documento, nos casos em que é legalmente admitida, deverá conter ou fazer-se acompanhar por este aviso.

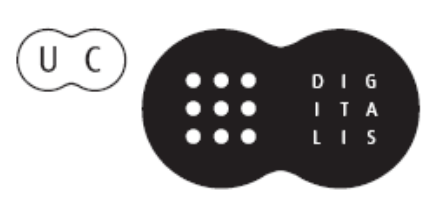




\section{ADVANCES IN}

\section{FOREST FIRE RESEARCH}

\section{8}

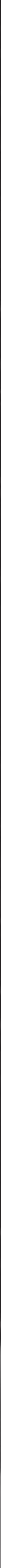




\title{
Influence of fire frequency and epoch of prescribed burn on topkill rates in vegetation of Cerrado in Tocantins, Brazil
}

\author{
Allan Deyvid Pereira da Silva ${ }^{1}$; Antonio Carlos Batista ${ }^{1}$; Marcos Giongo ${ }^{3}$; Micael Moreia Santos ${ }^{1}$; \\ Eduardo Ganassoli Neto ${ }^{1}$; Edmar Vinícius de Carvalho ${ }^{2}$; Igor Eloi Silva Machado ${ }^{1}$; Jader Nunes \\ Cachoeira ${ }^{1}$. \\ ${ }^{1}$ Federal University of Paraná, \{allanuft@gmail.com, batistaufpr@gmail.com, \\ moreirasmicael@gmail.com,eduardo.florestal@mail.uft.edu.br,igeloi@hotmail.com, \\ jadernunes@mail.uft.edu.br\} \\ ${ }^{2}$ Federal University of Tocantins, \{giongo@uft.edu.br, carvalho.ev@uft.edu.br\}
}

\begin{abstract}
The severity of fire can be understood as the level of change caused by a fire to a location. Considering the importance of fire in the Cerrado biome, the objective of this work was to evaluate the fire severity, expressed through suppression of the aerial part of the vegetation (topkill), in Cerrado environment. The research was performed at the ecological station Estação Ecológica Serra Geral do Tocantins, Jalapão region, Brazil. At areas with two, three and four years without occurrence of forest fires, identified by satellite images, prescribed burns were performed in the months of May, June, August and September of 2017. The fire severity was determined through the variation of the total number of individuals before and after the fire passage. At areas with four years with no occurrence of fires, regardless of the month in which the prescribed firing occurred, topkill values did not differ statistically (45 to 56\%). The three-year areas presented higher topkill values in September (66\%); and the areas of two years presented the highest rates in August (62.8\%). At conditions with greater accumulation of fuel material, due to the time without occurrence of fires, the period of the controlled burn (beginning of the drought or end of this season) did not influence the topkill rate of the vegetable individuals. Topkill rates among areas with different periods without burning varied only in September. The values of three and four-year areas (66 and 52.3\%, respectively) did not differ from each other ( $p>0,05)$ and were higher than rates at areas of two years with no occurrence of fire $(38 \%)$. The distinction of topkill rates at locations with different periods without occurrence of fires was only possible when the prescribed burn was performed at the end of the dry season in Cerrado; that is, the period that the climatic conditions contribute to lower air moisture content and forest fuels, thus increasing the burning efficiency.
\end{abstract}

Keywords: burn severity; fire severity; forest fires.

\section{Introduction}

The consumption of forest fuels, below and above the ground, is commonly titled as fire severity; and largely reflect fire intensity (Knox; Clarke, 2016).

The fire severity may reflect the variation of the dynamics of plant population and vegetation mortality; therefore, its measurement and recording are important (Keeley, 2009; Knox; Clarke, 2016).

The main factors that determine the intensity and severity of a forest fire are associated with the topography of the terrain, fuel characteristics and meteorological conditions at burning moment (Clarke et al., 2014; Lecina-Diaz et al., 2014; Soares et al., 2017).

In Cerrado, the drought commonly intensifies itself in early May and extends until mid-October, and the fuel accumulation is associated to the frequency of fires. In general, in Savanna environments, fire intervals of two to three years are common (Coutinho, 1990; Russell-Smith et al., 1997). 
The drought and fuel accumulation are important regarding level of fire severity. The suppression of the aerial part of the vegetable (topkill) has been used as a measure to evaluate the level of severity of forest fires in diverse researches in the world (Hoffmann; Solbrig, 2003; Nicholson et al., 2017).

The objective of this work was to evaluate the influence of the fire frequency and the period of burning about the variation of topkill rates in Cerrado of dirty field type.

\section{Methods}

The work was developed at the ecological station Estação Ecológica Serra Geral do Tocantins (EESGT), Jalapão region, Brazil. The area is a domain area of the Cerrado biome, composed, predominantly, by Campo Limpo and Campo Sujo. There are predominance of soils of the type Entisols; they can be leptsols (lithic entisol), fluvisols (fluvent entisol) and regosols (Psamment and Orthent entisol). The relief is relatively flat, with declivity equal or superior to 5\%; annual average temperature of $26^{\circ} \mathrm{C}$; annual mean rainfall of $1500 \mathrm{~mm}$ (Tocantins, 2012; MAPA, 2018b).

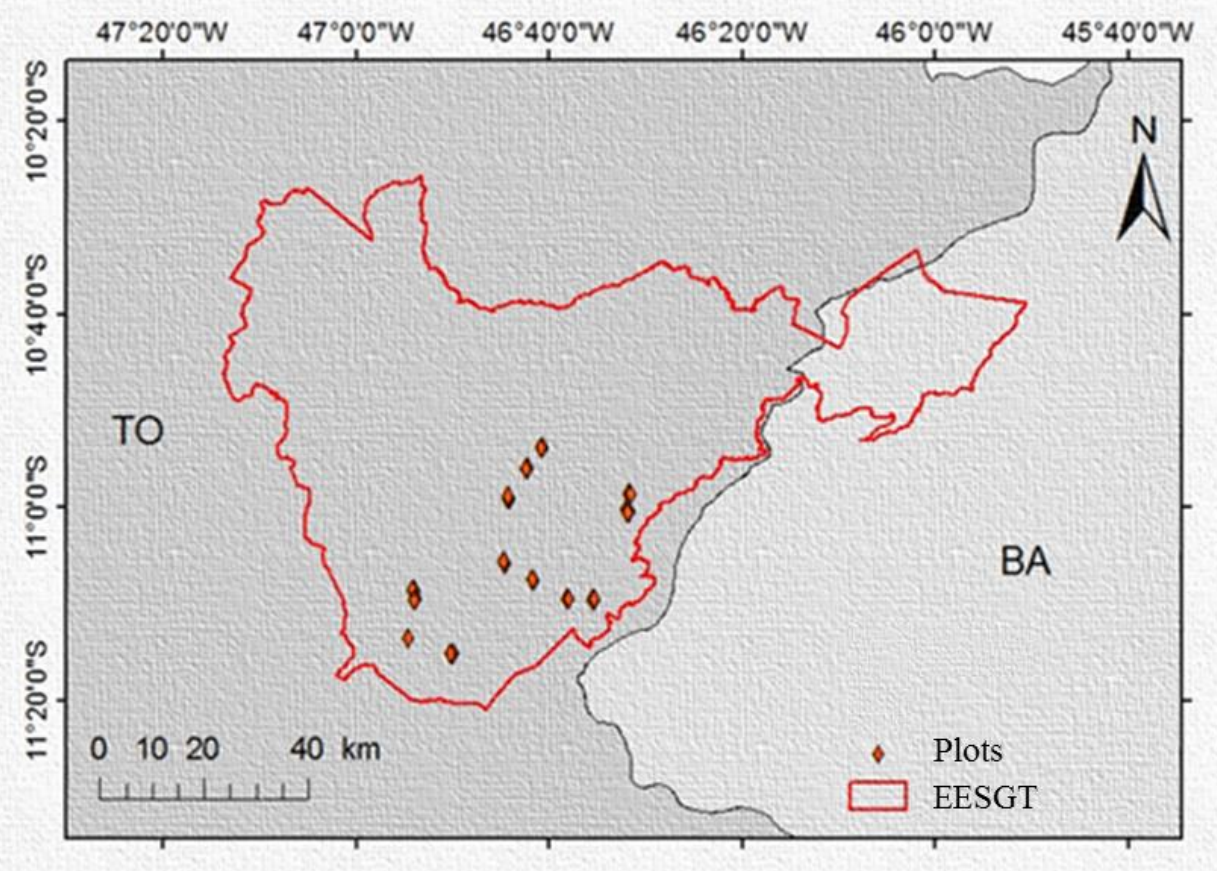

Figure 3 - Distribution of Experimental Areas at EESGT.

For the experiment, plots were established in areas with two, three and four years without occurrence of forest fires, identified through satellite images, where were performed prescribed burns in the months of May, June, August and September of 2017.

The treatments were composed of two factors: years without occurrence of fires versus season of prescribed burns). They were evaluated in four plots of $30 \times 30 \mathrm{~m}$, totaling 48 sample units randomly distributed at burning locations.

At each plot, for 20 possibilities, four sub-plots of $1 \mathrm{~m}^{2}$ were randomly drawn (Figure 2) and all vegetables up to $20 \mathrm{~mm}$ of diameter were counted - before and after the forest fire. The percentage of individuals whose aerial part was consumed by fire was considered as Topkill Rate - which was calculated with the following equation:

$$
\mathrm{TR}=\frac{(\mathrm{IBF}-\mathrm{IAF})}{\mathrm{IBF}} 100
$$


Being: TR - Topkill rate; IBF - number of individuals before fire; IAF - number of individuals after fire.

The forest fuel available for combustion (up to $1,8 \mathrm{~m}$ ) was quantified in 8 samples of $0,25 \mathrm{~m}^{2}$, randomly established at plot; and classified as living and dead material and as type (herbaceous). The material collected was dried in an oven at $70^{\circ} \mathrm{C}$ for 72 hours, weighed and its value converted to kg.m2.

The speed of fire propagation and the flame length were registered at the moment of fire front passage, based on $2,5 \mathrm{~m}$ height rulers, fixed to the plot and equidistant $3 \mathrm{~m}$ one from the other, perpendicular to the line of fire.

In order to statistically analyze the data, the test of normality was applied, followed by the factorial analysis of variance (years without fires versus season of prescribed burns) and the Scott-Knott test (p $>0,05)$.

\section{Results}

\subsection{Forest fuel and fire behavior}

The total biomass and herbaceous biomass available at areas with 2, 3 and 4 years without fires follow a pattern: load increase throughout time without occurrence of burning; and besides that, they present a predominance of dead vegetation (Table 1).

Table 1 - Characteristics of biomass among areas with different historical of the last burning and the fire behavior at each month of prescribed burns.

\begin{tabular}{|c|c|c|c|}
\hline \multicolumn{4}{|c|}{ Fuels characteristics } \\
\hline \multirow{2}{*}{ Biomass $\left(\mathrm{kg} \cdot \mathrm{m}^{-2}\right)$} & \multicolumn{3}{|c|}{ Fire frequency } \\
\hline & 2 years & 3 years & 4 years \\
\hline Total & $0,55(0,051)$ & $0,62(0,032)$ & $0,64(0,039)$ \\
\hline Living & $0,26(0,025)$ & $0,25(0,019)$ & $0,28(0,031)$ \\
\hline Dead & $0,30(0,038)$ & $0,37(0,024)$ & $0,37(0,020)$ \\
\hline Total herbaceous & $0,24(0,024)$ & $0,24(0,014)$ & $0,27(0,019)$ \\
\hline Living herbaceous & $0,10(0,010)$ & $0,08(0,006)$ & $0,09(0,010)$ \\
\hline Dead herbaceous & $0,14(0,019)$ & $0,16(0,013)$ & $0,18(0,012)$ \\
\hline \multicolumn{4}{|c|}{ Fire behavior } \\
\hline Season & Speed of prop & gation $\left(\mathrm{m} . \mathrm{s}^{-1}\right)$ & Flame length (m) \\
\hline 1 (Maio) & 0,20 & $, 047)$ & $2,51(0,390)$ \\
\hline 2 (Junho) & 0,20 & $, 031)$ & $2,60(0,282)$ \\
\hline 3 (Agosto) & 0,17 & $, 045)$ & $2,26(0,264)$ \\
\hline 4 (Setembro) & 0,41 & $, 036)$ & $3,68(0,211)$ \\
\hline
\end{tabular}

Values in parenthesis correspond to the standard error of the mean.

Among the different burning steps, the speed of propagation presented values from 0,17 to 0,41 m.s-1 (Table 1), being classified as extreme speed (Botelho; Ventura, 1990); and the flame length during burnings had values from 2,26 to $3,68 \mathrm{~m}$.

\subsection{Climate during research}

The monthly averages of meteorological variables considering the research period (Table 2) show that climate conditions varied among months with controlled burns, with May and June being both the most humid and with the lowest temperatures; August and September were both the hottest and the 
driest months. At Corredor Ecológico da Região do Jalapão (Ecological Corridor of Jalapão Region), the aforementioned characteristics are the normal conditions of beginning (May and June) and end (August and September) of the dry season, respectively (MMA, 2013).

Table 2 - Meteorological conditions during the period of the research (MAPA, 2018a).

\begin{tabular}{lccccc}
\hline Month/2017 & $\begin{array}{c}\text { Temperature } \\
\left({ }^{\circ} \mathrm{C}\right)\end{array}$ & $\begin{array}{c}\text { Relative } \\
\text { humidity } \\
(\%)\end{array}$ & $\begin{array}{c}\text { Wind } \\
\left(\mathrm{m}^{-1} \mathrm{~s}^{-1}\right)\end{array}$ & $\begin{array}{c}\text { Radiation } \\
\left(\mathrm{kJ} . \mathrm{m}^{2}\right)\end{array}$ & $\begin{array}{c}\text { Rainfall } \\
(\mathrm{mm})\end{array}$ \\
\hline May & 25,71 & 69,22 & 161,39 & 821,28 & 0,02 \\
June & 24,38 & 59,22 & 151,13 & 801,36 & 0,01 \\
August & 26,66 & 39,76 & 135,01 & 888,65 & 0,00 \\
September & 29,48 & 34,40 & 96,08 & 1380,42 & 0,00 \\
\hline
\end{tabular}

Only the average monthly precipitation did not differ by among months, being, actually, minimum and typical for the period at the study area. The climatic variability and forest fuel are the main determining factors of the fire behavior and, thus, are important for the dynamic comprehension of severity of fire under distinct conditions (Kane et al., 2015; Soares; Batista; Tetto, 2017).

\subsection{Topkill}

The evaluation of severity of fire in vegetation through topkill rate and the percentage of reduction of the number of vegetable individuals after burning show that (Table 2), among areas with different years without burning, the variation occurred only in September. The values of areas of three and four years without forest fires $(66,0$ and $52,3 \%$, respectively) did not differ by among them $(\mathrm{p}>0,05)$ and were higher than rate at areas with two years without fires $(37,8 \%)$. At the end of dry season, considering an area with seven yours without burnings, Hoffman and Solbrig (2003) verified topkill rates of $100 \%$. Thus, it is observed that in burnings performed at the end of dry season, topkill rates tend to increase at areas with higher period of fire suppression.

Table 3 - Topkill rate of vegetation (\%)

\begin{tabular}{lccc}
\hline \multirow{2}{*}{ Month } & \multicolumn{3}{c}{ Fire frequency } \\
\cline { 2 - 4 } & 2 years & 3 years & 4 years \\
\hline May & $29,5 \mathrm{Ab}$ & $32,3 \mathrm{Ab}$ & $45,0 \mathrm{Aa}$ \\
\hline June & $38,0 \mathrm{Ab}$ & $43,5 \mathrm{Ab}$ & $56,0 \mathrm{Aa}$ \\
\hline August & $62,8 \mathrm{Aa}$ & $43,8 \mathrm{Ab}$ & $48,8 \mathrm{Aa}$ \\
\hline September & $37,8 \mathrm{Bb}$ & $66,0 \mathrm{Aa}$ & $52,3 \mathrm{Aa}$ \\
\hline The statistical difference at $5 \%$ significance through Scott-Knott test; being capital letters \\
paring years without fires and lowercase letters the months of burning.
\end{tabular}

This variation observed only in September may be associated to the higher fuel load at areas of three and four years without burning (Table 1) and the meteorological conditions more propitious to burning of higher severity: greater air temperature $\left(29,48{ }^{\circ} \mathrm{C}\right)$, lower relative air humidity $(34,40 \%)$ and higher incidence of solar radiation $\left(1380,42 \mathrm{~kJ} / \mathrm{m}^{2}\right)($ Table 2$)$. These factors contributed for higher speed of fire propagation $(0,41 \mathrm{~m} / \mathrm{s})$ and larger flame length $(3,68 \mathrm{~m})$ (Table 1$)$.

At areas with two years without burning, the topkill rate was higher in August $(62,8 \%)$. This condition may be associated to a possible higher residence time of fire, in function of reduction of wind speed in this period (Table 1). According to Cochrane et al., (1999), the residence time contributes for increase on damage to vegetation. Besides that, the areas with two years without burning presented part of the vegetation with tender and thin stems, great part sprouted from the last 
fire, facilitating the consumption by fire at conditions of higher residence time. On the contrary, individuals with larger diameter stems and thicker bark tend to be more resilient to fire (Hoffmann; Solbrig, 2003; Hoffmann et al., 2009; Moreira et al., 2009).

At areas with three years without burning, the highest topkill rates occurred in September (66\%). These values are linked to the extreme drought conditions in this period (Table 2) which contributed for the largest flame length (Table 1).

Areas with four years without burning presented values between $45 \%$ and $56 \%$, which did not differ by statistically among them ( $p>0,05)$. These results show that at areas with higher accumulation of fuel material, due to period of time without burning occurrences, the period of burning (beginning or end of the dry season) was not capable of differentiating topkill rates. From the fire triangle (fuel, heat and oxygen), the fuel is, probably, the most complex component, since it varies in quantity, geometry, density, continuity and chemical characteristics (Parsons et al., 2016; Soares et al., 2017). May the homogeneity of topkill rates at areas of four years without burning be associated to the higher fuel quantity in comparison to the areas with three and two years (Table 1). These factors favored a more homogeneous behavior of fire in these areas.

\section{Conclusion}

Only at areas with four years of fuel accumulation there was not variation in topkill rates throughout the months of burning. Regarding the comparison among areas with two, three and four years of fuel accumulation, difference was only observed in September - the end of the dry season.

\section{References}

Botelho, H. S., \& Ventura, J. (1990). Modelos de comportamento do fogo. A técnica do fogo controlado. Universidade de Trás-os-Montes e Alto Douro: Vila Real, 49-55.

Clarke, P. J., Knox, K. J., Bradstock, R. A., Munoz-Robles, C., \& Kumar, L. (2014). Vegetation, terrain and fire history shape the impact of extreme weather on fire severity and ecosystem response. Journal of vegetation science, 25(4), 1033-1044. Doi:10.1111/jvs.12166

Cochrane, M. A., Alencar, A., Schulze, M. D., Souza, C. M., Nepstad, D. C., Lefebvre, P., \& Davidson, E. A. (1999). Positive feedbacks in the fire dynamic of closed canopy tropical forests. Science, 284(5421), 1832-1835. Doi:10.1126/science.284.5421.1832

Coutinho, L.M. (1990). Fire in the ecology of the Brazilian cerrado. In: Goldhammer, J.G. (Ed.), Fire in the Tropical Biota. Springer, Berlin, pp. 82-105. Doi: 10.1007/978-3-642-75395-4_6

Hoffmann, W. A., \& Solbrig, O. T. (2003). The role of topkill in the differential response of savanna woody species to fire. Forest ecology and management, 180(1-3), 273-286. Doi:10.1016/S03781127(02)00566-2

Hoffmann, W. A., Adasme, R., Haridasan, M., De Carvalho, M.T., Geiger, E. L., Pereira, M. A.B., Gotsch, S.G., \& Franco, A. C. (2009). Tree topkill, not mortality, governs the dynamics of savannaforest boundaries under frequent fire in central Brazil. Ecology, 90(5), 1326-1337. Doi:10.1890/080741.1

Kane, V. R., Cansler, C. A., Povak, N. A., Kane, J. T., McGaughey, R. J., Lutz, J. A., Churchill, D. J. \& North, M. P. (2015). Mixed severity fire effects within the Rim fire: relative importance of local climate, fire weather, topography, and forest structure. Forest Ecology and Management, 358, 6279. Doi:10.1016/j.foreco.2015.09.001

Keeley, J. E. (2009). Fire intensity, fire severity and burn severity: a brief review and suggested usage. International Journal of Wildland Fire, 18(1), 116-126. Doi:10.1071/WF07049 
Knox, K. J., \& Clarke, P. J. (2016). Measuring fire severity: Are canopy, understorey and belowground measures coupled in sclerophyll forest fires?. Plant ecology, 217(6), 607-615. Doi:10.1007/s11258-016-0609-6

Lecina-Diaz, J., Alvarez, A., \& Retana, J. (2014). Extreme fire severity patterns in topographic, convective and wind-driven historical wildfires of Mediterranean pine forests. PloS one, 9(1), e85127. Doi:10.1371/journal.pone.0085127

MAPA - Ministério da Agricultura, Pecuária e Abastecimento. (2018a). Banco de Dados Meteorológicos para Ensino e Pesquisa - BDMEP. Instituto Nacional de Meteorologia. Disponível em: 〈http://www.inmet.gov.br/projetos/rede/pesquisa/>, acesso em: 27 de março de 2018.

MAPA - Ministério da Agricultura, Pecuária e Abastecimento. (2018b). Embrapa Solos. Correspondência entre classes do SiBCS, WRB/FAO e Soil Taxo. Disponível em: <https://www.embrapa.br/solos/sibcs/correlacao-com-wrb-fao-e-soil-taxonomy>, acesso em: $27 \mathrm{de}$ março de 2018.

MMA - Ministério do Meio Ambiente. (2013). Atlas do corredor ecológico da região do Jalapão. Instituto Chico Mendes de Conservação da Biodiversidade - ICMBio, 2.

Moreira, F., Catry, F., Duarte, I., Acácio, V., \& Silva, J. S. (2009). A conceptual model of sprouting responses in relation to fire damage: an example with cork oak (Quercus suber L.) trees in Southern Portugal. Plant Ecology, 201(1), 77-85. Doi:10.1007/s11258-008-9476-0

Nicholson, Á., Prior, L. D., Perry, G. L., \& Bowman, D. M. (2017). High post-fire mortality of resprouting woody plants in Tasmanian Mediterranean-type vegetation. International Journal of Wildland Fire, 26(6), 532-537. Doi:10.1071/WF16211

Parsons, R., Jolly, W. M., Hoffman, C., \& Ottmar, R. (2016). The Role of Fuels in Extreme Fire Behavior. Synthesis of Knowledge of Extreme Fire Behavior, 55-82.

Russell-Smith, J., Ryan, P. G., \& Durieu, R. (1997). A LANDSAT MSS-Derived fire history of kakadu national park, monsoonal northern australial, 1980-94: Seasonal extent, frequency and patchiness. Journal of Applied Ecology, 34 (3), 748-766. Doi:10.2307/2404920

Soares, R., V., Batista, A., C.; \& Tetto, A.F. (2017). Incêndios florestais: controle, efeitos e uso do fogo. Ronaldo Viana Soares and Antonio Carlos Batista independent publisher. Curitiba, PR (Brazil). 255 p.

Tocantins (2012). Atlas do Tocantins: subsídios ao planejamento da gestão territorial. Secretaria do Planejamento e da Modernização da Gestão Pública-SEPLAN, 6. 